\title{
KARAKTERISTIK INDIVIDU DAN PERILAKUKEWIRAUSAHAAN PENGUSAHA PRODUK UNGGULAN USAHA KECIL DAN MENENGAH KABUPATEN LUMAJANG
}

\author{
Andri Bachtiar \\ Department of Management FEB UMM \\ E-mail: Andribachtiar1105@gmail.com
}

\begin{abstract}
The research aims to determine the characteristics of the individual entrepreneur's flagship product in small and medium enterprises Lumajang. Analysis tools used is the range of scale and cross tabulation. The result indicated that entrepreneur's characteristic were high responsible, seeking an opportunities, resistant to risks and uncertainties, confidence, creative and flexible, require quick feedback, high energy level, motivation to excel, future-oriented, always learn from failure, and the ability to lead. The characteristics of entrepreneurial attitudes and behaviors are still need to increase in order to compete with others.
\end{abstract}

\section{Keywords: Individual Characteristics, Behavior, UKM}

\section{PENDAHULUAN}

Kondisi perekonomian di Indonesia di berbagai bidang belakangan ini tidak menunjukkan perubahan berarti, kebijakan pemerintah masih simpang siur, hukum semakin tidak jelas, musibah di mana-mana, dan kondisi sosial semakin tidak menentu. Di bidang ekonomi, tidak ada perubahan kearah yang lebih baik, PHK tetap berlangsung karena banyak wirausahawan tidak lagi berminat memulai atau mengembangkan usahanya, dan para investor asing sudah banyak yang memutuskan untuk memindahkan usahanya ke negara lain yang lebih menjanjikan. Di sisi lain, jumlah populasi dengan usia produktif tidak bisa begitu saja menganggur. Hidup tetap harus berjalan dan penghasilan tetap mesti dicari untuk menutupi biaya hidup yang semakin mahal. Berbagai ide bisnis bermunculan dan di diskusikan dalam berbagai forum pertemuan baik formal maupun informal. Sebagian ide tersebut memang hanya merupakan "mimpi yang indah" tetapi sebagian lagi ditanggapi dengan antusiasme yang tinggi. Dari hal ini terlihat bahwa masyarakat kita justru merasa terpacu ketika dihadapkan pada suatu krisis yang berkepanjangan dan mencoba untuk bangkit.

Sumbangan kewirausahaan terhadap pembangunan ekonomi suatu negara tidaklah disangsikan lagi. Suatu negara agar dapat berkembangdan dapat membangun secara ideal, harus memilikiwirausahawan sebesar $2 \%$ dari jumlah penduduk. Sektor Wirausaha ini menjadi sangat strategis, karena potensinya yang 
besar dalam menggerakkan kegiatan ekonomi masyarakat dan sekaligus menjadi harapan sumber pendapatan sebagian besar masyarakat serta menyerap tenaga kerja baru. Sebagaimana diketahui angka pengangguran yang cukup besar di Indonesia dikarenakan Perusahaan besar tidak bisa menyerap angkatan kerja baru, sementara usaha kecil dan menengah masih sangat sedikit untuk menyerap angkatan kerja yang banyak, sektor UKM juga memilik masalah dalam sistem manajemennya.

\section{Perkembangan Usaha Kecil}

dan Menengah di Kabupaten Lumajang belakangan ini cukup menunjukkan perkembangan yang baik, hal ini dapat dilihat dari semakin bertambahnya pelaku usaha kecil dan menengah. Kabupaten Lumajang yang berjuluk sebagai kota Pisang tidak terlepas dari usaha kecil yang berbahan baku pisang, dan tentunya banyak produk unggulan yang dihasilkan oleh kabupaten Lumajang, Dari data situs resmi Kabupaten Lumajang di www.lumajang.co.id saat ini jumlah wirausahwan di Kabupaten Lumajang mencapai $23 \%$ tapi hanya $0,05 \%$ yang menjadi wirausahawan modern dalam artian yang mampu mengatur usahanya menjadi usaha yang mempunyai prospek baik dan manajemen yang baik serta mampu berkembang dan memiliki daya saing baik nasional maupun internasional, sebenarnya Kabupaten Lumajang memiliki banyak sektor usaha kecil dan menengah, tetapi ada 2 sektor yang paling berkembang dan memiliki prospek baik dan menjadi unggulan Kabupaten Lumajang diantaranya adalah keripik pisang, dan kerajinan perak Jokarto.

Usaha Kecil Menengah yang menghasilkan produk kripik pisang di Kecamatan Senduro adalah sentra usaha kripik pisang terbesar di Kabupaten lumajang yang mampu menyediakan lapangan pekerjaan bagi warga setempat, usaha kecil yang terletak di Desa Burno ini masih menggunakan cara tradisional dalam pengolahannya, meski dalam pengolahannya menggunakan semifabrikasi, dengan jumlah wirausahawan 25 orang setiap bulannya UKM menghasilkan 165 ton dengan Merk UKM Burnosari, pemasaran keripik pisang ini mencapai beberapa kota di Jawa Timur maupun di luar provinsi termasuk Jakarta dan juga sudah menembus pasar luar negeri yang diantaranya Hongkong dan Singapura yang mencapai Rp 22 milliar.

Produk unggulan yang kedua adalah kerajinan perak Lumajang yang sudah terkenal bahkan sampai ke manca negara, sejauh ini kerajinan perak Lumajang termasuk yang terbesar selain kerajinan perak kota Gedhe di Jogjakarta dan kerajinan perak Celuk di Bali, ada lima kecamatan di Lumajang yang menjadi sentra kerajinan perak dengan jumlah wirausahawan 20 yang tersebar di Kecamatan Tempeh, Pasirian, Sumbersuko, Pasrujambe dan Candipuro, sedangkan untuk pelaku terbanyak kerajinan perak berada di Kecamatan Tempeh yaitu di Desa Mbesuk, Jatisari, Jokarto dan Pulo.

Mutu dan kualitas kerajinan perak Lumajang terkenal baik di dalam dan luar negeri karena didukung oleh sumber daya manusia 
yang berkualitas. Kapasitas produksi mencapai $11.721 \mathrm{~kg}$ per hari dengan total nilai investasi Rp 929.379.000. UD Karya Abadi adalah salah satu penghasil kerajinan perak yang tercatat mempekerjakan tenaga kerja paling banyak. Didirikan tahun 1992 oleh Ngadiwiyono dengan karyawan delapan orang. Kemudian seiring dengan melesatnya pengembangan usaha serta pesatnya laju permintaan kerajinan perak dari berbagai daerah juga mulai merintis pasar luar negeri, karyawan yang semula hanya delapan orang meningkat menjadi 80 orang.

$$
\text { Karakteristik individu }
$$

wairausahawan di Kabupaten Lumajang mayoritas individu berjenis kelamin perempuan, wirausahawan wanita didefinisikan sebagai pemilik dari bisnis yang memiliki inisiatif, menerima segala resiko dan keuangan, bertanggung jawab secara administrasi dan sosial dan efektif memimpin dalam manajemennya ditinjau dari usia mayoritas berusia 40 tahun dengan tingkat pendidikan yang bervariasi dari yang memiliki tingkat pendidikan yang paling dasar yaitu SD sampai Sarjana tetapi mayoritas tingkat pendidikannya adalah SD, sedangkan apabila ditinjau dari lama mereka berwirausaha mayoritas sudah menjalankan usahanya lebih dari 5 tahun dengan tingkat penghasilan antara karakter yang masuk kategori sangat tinggi yaitu komitmen dan tekat yang bulat untuk mencurahkan semua perhatian pada usahanya, ambisi mencari peluang usaha, kreatifitas dan fleksibel menanggapi permintaan pasar, dan kemampuan memimpin/ mengolah usahanya. Secara teoritis dapat dikatakan bahwa menjadi seorang wirausahawan harus mempunyai sikap dan perilaku kewirausahaan diatas meskipun tidak secara keseluruhan karakteristik tersebut ada pada wirausahawan namun semakin banyak karakteristik yang dimiliki maka kemungkinan untuk berhasi dan meraih kesuksesan akan semakin besar peluangnya.

\section{TINJAUAN PUSTAKA}

Penelitian terdahulu yang dijadikan sebagai landasan adalah "Analisis Karakteristik Individu dengan Sikap dan Perilaku Kewirausahaan pada Wirausahawan Produk Unggulan Kecil dan Menengah Kota Malang”. Tujuan dari penelitian ini adalah untuk mengetehui jiwa kewirausahaan para wirausahawan produk unggulan di Kota Malang. Teknik yang digunakan yaitu dengan menggunakan rentang skala dan tabulasi silang. Hasil dari penelitian terdahulu adalah tingkat pendidikan yang tinggi tidak terlalu berpengaruh secara segnifikan terhadap kemajuan usaha, melainkan pengalaman dalam bidang usaha itu sendiri yang lebih menentukan pencapaian kerja

Dari hasil analisi diatas dapat diketahui bahwa jiwa kewirausahaan pada pengusaha dapat menunjang berkembangnya usaha dan menuju kesuksesan, Karakteristik individu wirausahawan di Kota Malang ditinjau dari usia mereka mayoritas sudah berusia diatas 40 tahun dengan tingkat pendidikan bervariasi dari yang memiliki tingkat pendidikan terendah yaitu SD sampai tingkat pendidikan tertinggi yaitu Sarjana.

Selain didasarkan pada penelitian terdahulu, penelitian saat ini juga berdasarkan pada pendapat 
Peter F. Drucker yang menyatakan kiwirausahaan adalah kemampuan untuk menghasilkan sesuatu yang baru dan berbeda, Hal ini mendorong Thomas F. Zimmerer menggabungkan, memperluas karakteristik sikap dan perilaku kewirausahaan yang berhasil antara lain, Commitment and determination, Desire for responbility, Opportunity obsession, Tolerance for risk, ambiguity and uncertainty, Self confidence, Creativity and flexibelity, Creativity and flexibelity, High level of energy, Motivation to excel, Orientation to the future, Willingness to learn from future, and Leadership ability. Sedangkan Karakterisktik dalam perilaku Organisasi dapat juga berarti tabiat, watak, perangai perbuatan yang selalu dilakukan dan mempengaruhi segenap pikiran dan tingkah laku juga pengambilan keputusan kerja (Ivancevich, 2005).

Berdasarkan teori tersebut peneliti ingin membuktikan apakah karakteristik perilaku kewirausahaan yang terdapat pada para wirausahawan pada produk unggulan Kabupaten Lumajang sesuai dengan teori tersebut atau tidak.

Persamaan antara penelitian terdahulu dengan penelitian sekarang adalah obyek penelitian yang digunakan berkaitan dengan wirausahawan, akan tetapi terdapat perbedaan antara penelitian sekarang dengan penelitian terdahulu yaitu lokasi penelitian, tahun penelitian dan obyek yang diteliti.

Kewirausahaan berasal dari kata entrepreneurship yang diartikan sebagai "the backbone of economy" yaitu syaraf pusat perekonomian. Secara epidemiologi, kewirausahaan merupakan nilai yang diperlukan untul memulai suatu usaha atau suatu proses untuk menghasilkan sesuatu yang baru berdasarkan ide - ide dan gagasan yang baru. Kewirausahaan menurut Peter F. Drucker adalah kemampuan untuk menghasilkan sesuatu yang baru dan berbeda (Kasmir, 2006). Pengertian ini mengandung arti bahwa seorang wirausahawan harus bisa menuangkan ide dan gagasannya untuk menghasilkan sesuatu yang baru dan berbeda.

Menurut

Meredith berwirausaha berarti memadukan watak pribadi, keuangan dan sumber daya. Oleh karena itu, berwirausaha merupakan suatu pekerjaan yang membutuhkan keahlian untuk melihat peluang yang ada serta mampu memanfaatkan peluang dengan sikap dan kepemimpinan individu yang baik guna untuk mencapai tujuan. (Suryana, 2006).

Karakteristik berasal dari kata karakter, dalam Kamus Besar Bahasa Indonesia definisi karakter adalah sifat-sifat kejiwaan, akhlak atau budi pekerti yang membedakan seseorang dengan orang lain. Karakterisktik dalam perilaku Organisasi dapat juga berarti tabiat, watak, perangai perbuatan yang selalu dilakukan dan mempengaruhi segenap pikiran dan tingkah laku juga pengambilan keputusan kerja. Jadi karakteristik memiliki arti luas adalah ciri ciri dari individu yang terdiri dari demografi seperti jenis kelamin, umur, pendidikan, pekerjaan, ras, status ekonomi dan sebagainya (Widianingrum, 1999).

Berdasarkan pengertian karakteristik diatas, maka dapat disimpulkan definisi karakteristik wirausahawan adalah ciri khas 
seseorang, watak atau karakter, corak tingkah laku, sebagai identitas seseorang yang melekat pada wirausahawan dalam menjalankan usahanya. Dalam penelitian ini peneliti akan mencari pengaruh dari karakteriktik wirausahawan terhadap perkembangan usahanya, khususnya di Kabupaten Lumajang. Karakteristik wirausaha menunjukkan sifat atau ciri wirausahawan (Suryana, 2003).

Sikap merupakan kesiapan untuk bereaksi terhadap obyek di lingkungan tertentu sebagai suatu penghayatan terhadap obyek tersebut. Menurut G.W Allport yang dikutip David O. Sears (1999) "Sikap adalah keadaan mental dari kesiapan, yang diatur melalui pengalaman yang memberikan pengaruh dinamik atau terarah respon individu pada suatu objek dan sesuatu yang berkaitan dengannya". Sedangkan menurut Sigit (2008) "Sikap adalah tanggapan seseorang terhadap suatu stimulasi yang menimbulkan tangkapan kognitif (pikiran), afektif (penilain) dan kognitif (kecenderungan perilaku)".

Berdasarkan pada definisi pengertian sikap tersebut maka dalam penelitian ini akan mencari hubungan sikap wirausahawan terhadap perkembangan usaha, apakah cukup signifikan mempengaruhi perkembangan usaha dan daya saingnya terhadap wirausaha lain di sektor yang sama yang terdapat di Kabupaten Lumajang.

Sikap terdiri dari tiga komponen yang mempengaruhi. Ketiga komponen tersebut merupakan indikator sikap seseorang terhadap suatu obyek yang terdiri dari Aspek Kognitif yang berisi kepercayaan seseorang mengenai apa yang berlaku atau apa yang benar bagi obyek sikap. Komponen kognitif merupakan gambaran apa yang dipercayai oleh individu pemilik sikap. Menurut Sigit (2000) yang dimaksud kognitif (cognitif) ialah seberapa tahu seseorang menanggapi informasi yang didapat dan apakah ia benar-benar mengetahuinya.

Aspek afektif, Menurut Azwar (2002), "Komponen afektif merupakan persuasi individu terhadap obyek sikap dan menyangkut masalah emosi". Aspek konatif, yaitu berwujud proses kecenderungan (tendensi) untuk berbuat suatu obyek tertentu. Menurut Sigit (2003) konatif (conative) merupakan kemampuan untuk berbuat (berperilaku) terhadap obyek untuk mengenal (utuh) dan memiliki terhadap obyek yang disukai.

Perilaku adalah sikap dan tindakan atau semua yang dilakukan manusia, misalkan bekerja dengan giat atau malas berkomunikasi dengan teman atau bawahannya, menolak atau menerima tugas yang diberikan dan sebagainya. Perilaku individu dalam organisasi adalah sikap dan tindakan (tingkah laku) seorang manusia (individu) dalam organisasi sebagai ungkapan dari kepribadian, persepsi dan sikap jiwanya, dimana bisa berpengaruh terhadap prestasi (kinerja) dirinya dan organisasinya (Mohyi, 2009). Dari definisi tersebut dapat dijelaskan bahwa komponen perilaku individe terdiri atas sikap, persepsi dan kepribadian yang membentuk sebuah perilaku individu.

Perilaku kewirausahaan adalah suatu sifat seseorang yang 
terbentuk karena kebiasaan seharihari yang mempengaruhi pengambilan keputusan dalam suatu organisasi atau kelompok. Enam ciri perilaku kewirausahaan, yaitu: 1 . Keterampilan mengambil keputusan dan risiko yang moderat dan bukan atau kebetulan belaka. 2. Energik, khususnya dalam bentuk berbagai kegiatan inovatif. 3. Tanggung jawab individual. 4. Mengetahui hasil-hasil dari berbagai keputusan yang diambilnya dengan tolak ukur satuan uang sebagai indikator keberhasilan. 5. Mampu mengantisipasi berbagai kemungkinan dimasa datang. 6 . Memiliki kemampuan berorganisasi, yang meliputi kemampuan kepemimpinan dan manajerial. (Suryana, 2003).

\section{METODE PENELITIAN}

Lokasi penelitian dilaksanakan pada produk unggulan usaha kecil dan menengah di Kabupaten lumajang. Alasan mengambil lokasi penelitian ini karena produk-produk unggulan Usaha Kecil Menengah di Kota Lumajang memiliki ciri khas yang berbeda dengan produk dari daerah lain, produk khas dari kabupaten Lumajang ini mampu bersaing dengan produk-produk sejenis dari daerah lain, produk unggulan yang menjadi pendapatan daerah Kabupaten Lumajng antara lain, olahan dari pisang yang menjadi maskot dari Kabupaten Lumajang, dan Kerajinan perak yang mampu merambah ke pasar Internasional.

Jenis penelitian adalah penelitiaan survey Menurut Sugiyono (2003), penelitian survey yaitu penelitian yang dilakukan pada populasi besar maupun kecil, tetapi data yang dipelajari adalah data dari sampel yang diambil dari populasi tersebut dan menggunakan kuisioner sebagai alat pengumpulan data yang pokok.

Dalam penelitian ini peneliti mengambil populasi dari Jumlah wirausahawan Keripik Pisang dan Kerajinan Perak di Kabupaten Lumajang yang tersebar di beberapa UKM ada 45 wirausaha. Sampel penelitian ini adalah Wirausahawan yang bergerak dalam indutri keripik pisang, yang menjadi andalan UKM Kabupaten Lumajang.

Menurut Arikunto (2012) teknik pengambilan sampel adalah apabila subyeknya kurang dari 100 maka lebih baik diambil semua sehingga menggunakan penelitian populasi, selanjutnya jika subyeknya lebih dari 100 makan sampel yang diambil antara $10 \%-15 \%$ atau $20 \%$ $25 \%$ tergantung dari luas wilayah, dana, waktu dan tenaga.

Pada penelitian ini peneliti menggunakan teknik sampling probabilitas yang merupakan teknik sampling yang dilakukan dengan memberikan peluang atau kesempatan kepada semua anggota populasi untuk menjadi sampel dalam penelitian ini, dengan tujuan agar sampel yang diperoleh merupakan sampel yang respresentatif.

Metode pengumpulan data dalam penelitian ini meliputi: kuisioner adalah cara pengumpulan data dengan membuat daftar pertanyaan dan diajukan peneliti kepada responden untuk memperoleh jawaban yang sesuai dengan data yang diinginkan. Wawancara adalah pengumpulan data dengan mengadakan tanya jawab langsung perilaku kepada para Wirausahawan 
mengenai proses produksi mereka. Observasi adalah menjaring data, fakta, informasi secara langsung dengan cara mengamati, melihat ditempat penelitian dan melakukan pencatatan secara sistematis terhadap objek yang diteliti.

Teknik analisis data yang digunakan adalah rentang skala digunakan untuk mendeskripsikan Karakteristik individu para wirausahawan terhadap perilaku kewirausahaanya.

\section{HASIL PENELITIAN DAN PEMBAHASAN}

Berdasarkan hasil perhitungan rentang skala di atas dapat diketahui bahwa indikator komitmen dan tekad yang bulat terhadap usahanya (Y.1) masuk dalam kriteria sangat tinggi, hal ini dikarenakan para usahawan sangat ingin mengembangkan usaha yang dijalankannya meskipun banyak rintangan yang dilalui, dengan demikian dapat disimpulkan bahwa wirausahawan produk unggulan Usaha Menengah Kota Lumajang memiliki komitmen dan tekad yang bulat untuk mencurahkan semua perhatiannya pada usaha yang sedang dijalankan.

Berdasarkan hasil perhitungan rentang skala di atas dapat diketahui bahwa indikator rasa tanggungjawab (Y.2) masuk dalam kriteria tinggi, dengan demikian dapat disimpulkan bahwa wirausahawan produk unggulan Usaha Kecil Menengah Kota Lumajang memiliki rasa tanggung jawab yang tinggi baik tanggung jawab dalam mengendalikan sumber daya yang digunakan maupub tanggung jawab terhadap keberhasilan berwirausaha.
Berdasarkan hasil perhitungan rentang skala di atas dapat diketahui bahwa indikator berambisi mencari peluang (Y.3) masuk dalam kritaria sangat tinggi, dengan demikian dapat disimpulakn bahwa wirausahawan produk unggulan Usaha Kecil Menengah Kota Lumajang selalu berambisi untuk selalu mencari peluang dan keberhasilan wirausaha selalu diukur dengan keberhasilan untuk mencapai tujuan, dari pencapaian tujuan terjadi apabila ada peluang.

Berdasarkan hasil perhitungan rentang skala di atas dapat diketahui bahwa indikator tahan terhadap risiko dan ketidakpuasan (Y.4) masuk dalam kriteria tinggi, dengan demikian dapat disimpulkan bahwa wirausahawan produk unggulan Usaha Kecil Menengah Kota Lumajang memiliki daya tahan terhadap risiko dan ketidakpuasan dalam menjalankan usahanya.

Berdasarkan hasil perhitungan rentang skala di atas dapat diketahui bahwa indikator rasa percaya diri (Y.5) masuk dalam kriteria tinggi, dengan demikian dapat disimpulkan bahwa wirausahawan produk unggulan Usaha Kecil Menengah Kota Lumajang cenderung optimis dan memiliki keyakinan yang kuat terhadap kemampuan yang dimilikinya untuk berhasil.

Berdasarkan hasil perhitungan rentang skala di atas dapat diketahui bahwa indikator tingkat energi yang tinggi (Y.8) masuk dalam kriteria tinggi, dengan demikian dapat disimpulkan bahwa wirausahawan produk unggulan Usaha Kecil Menengah Kota Lumajang merupakan pekerja keras dan 
Tabel 1. Karakteristik Responden

\begin{tabular}{lcc}
\hline \multicolumn{1}{c}{$\begin{array}{c}\text { Karakteristik } \\
\text { Responden }\end{array}$} & $\begin{array}{c}\text { Jumlah } \\
\text { Responden } \\
\text { (orang) }\end{array}$ & $\begin{array}{c}\text { Jumlah } \\
\text { Prosentase } \\
(\%)\end{array}$ \\
\hline Berdasarkan Jenis Kelamin & 17 & $37,8 \%$ \\
$\quad$ Pria & 28 & $62,2 \%$ \\
$\quad$ Wanita & & \\
Berdasarkan Usia & 7 & $15,6 \%$ \\
31 sd 40 th & 20 & $44,4 \%$ \\
41 sd 50 th & 13 & $28,9 \%$ \\
51 sd 60 th & 5 & $11,1 \%$ \\
>60 & & \\
Berdasarkan Pendidikan & 16 & $35,6 \%$ \\
SD & 14 & $31,1 \%$ \\
SMP & 8 & $17,8 \%$ \\
SMA & 2 & $4,4 \%$ \\
Doploma & 5 & $11,1 \%$ \\
Sarjana & & \\
Berdasarkan Lama Usaha & 5 & $11,1 \%$ \\
0 sd 5 th & 11 & $24,4 \%$ \\
6 sd 10 th & 17 & $37,8 \%$ \\
11 sd 15 th & 12 & $26,7 \%$ \\
Berdasarkan Tingkat Penghasilan & & \\
500 rb sd 3 jt & 32 & $71,1 \%$ \\
3 jt sd 5 jt & 6 & $13,3 \%$ \\
>7 sd 7 jt & 4 & $8,9 \%$ \\
\hline
\end{tabular}

Tabel 2. Karakteristik sikap dan perilaku kewirausahaan

\begin{tabular}{|c|c|c|c|c|c|c|c|c|}
\hline \multirow[t]{2}{*}{ No } & \multirow[t]{2}{*}{ Indikator } & \multicolumn{4}{|c|}{$\begin{array}{l}\text { Jawaban } \\
\text { responden }\end{array}$} & \multirow{2}{*}{$\sum_{\text {Responden }}$} & \multirow{2}{*}{$\sum_{\text {Skor }}$} & \multirow[t]{2}{*}{ Kriteria } \\
\hline & & STs & TS & $\mathrm{S}$ & SS & & & \\
\hline 1 & Y.1 & 0 & 5 & 24 & 16 & & 147 & Sangat Tinggi \\
\hline 2 & Y.2 & 0 & 3 & 39 & 3 & & 135 & Tinggi \\
\hline 3 & Y.3 & 0 & 4 & 30 & 11 & & 142 & Tinggi \\
\hline 4 & Y.4 & 0 & 4 & 35 & 6 & & 137 & Tinggi \\
\hline 5 & Y.5 & 0 & 7 & 30 & 8 & & 128 & Tnggi \\
\hline 6 & Y.6 & 0 & 3 & 28 & 14 & 45 & 148 & Sangat Tinggi \\
\hline 7 & Y.7 & 0 & 4 & 33 & 8 & & 139 & Tinggi \\
\hline 8 & Y.8 & 0 & 7 & 21 & 17 & & 147 & Sangat Tinggi \\
\hline 9 & Y.9 & 0 & 8 & 23 & 14 & & 141 & Tinggi \\
\hline 10 & Y.10 & 0 & 3 & 33 & 9 & & 141 & Tinggi \\
\hline 11 & Y.11 & 0 & 3 & 31 & 11 & & 143 & Tinggi \\
\hline 12 & Y.12 & 0 & 2 & 21 & 22 & & 155 & Sangat Tinggi \\
\hline
\end{tabular}


bersungguh-sungguh dalam menjalankan usahanya walaupun dalam waktu yang relatif lama.

Berdasarkan hasil perhitungan rentang skala di atas dapat diketahui bahwa indikator motivasi untuk unggul (Y.9) masuk dalam kriteria tinggi, dengan demikian dapat disimpulkan bahwa wirausahawan produk unggulan Usaha Kecil Menengah Kota Lumajang selalu ingin lebih unggul, selalu kreatif dalam mengerjakan apa yang dilakukannya dengan motivasi mencapai yang selalu diinginkan.

Berdasarkan hasil perhitungan rentang skala di atas dapat diketahui bahwa indikator berintregasi pada masa depan (Y.10) masuk dalam kriteria tinggi, dengan demikian dapat disimpulkan bahwa wirausahawan produk unggulan Usaha Kecil Menengah Kota Lumajangn berpandangan jauh ke masa depan yang lebih baik untuk dapat mencapai keberhasilan dalam menjalankan usahanya.

Berdasarkan hasil perhitungan rentang skala di atas dapat diketahui bahwa indikator selalu belajar dari kegagalan (Y.11) masuk dalam kriteria tinggi, dengan demikian dapat disimpulkan bahwa wirausahawan produk unggulan Usaha Kecil Menengah Kota Lumajang selalu belajar dari kegagalan yang pernah dialami sehingga dalam mengambil keputusan para wirausahawan selalu berkaca pada pengalaman yang sebelum-sebelumnya.

Berdasarkan hasil perhitungan rentang skala di atas dapat diketahui bahwa indikator kemampuan memimpin/ mengolah usahanya (Y.12) masuk dalam kriteria sangat tinggi, dengan demikian dapat disimpulkan bahwa wirausahawan produk unggulan Usaha Kecil Menengah Kota Lumajang memiliki kemampuan untuk mengolah dan menjalankan usaha dengan baik sesuai dengan harapan.

Dari 12 indikator tersebut terdapat 4 indikator yang masuk dalam kriteria sangat tinggi, sedangkan 8 indikator lainnya masuk dalam kategori tinggi. Hal ini menunjukkan bahwa sikap dan perilaku wirausahawan pada wirausahawan produk unggulan Usaha Kecil Menengah Kota Lumajang bisa dikatakan baik.

Komitmen dan tekat yang bulat untuk mencurahkan semua perhatian pada usaha Kerajinan Keripik Pisang, Komitmen dan tekat yang bulat untuk mencurahkan semua perhatian pada usaha Kerajinan Keripik Pisang.

Berambisi mencari peluang pada Kerajinan Keripik Pisang, Jika ditinjau dari jenis kelamin mayoritas perempuan, hal ini menunjukkan bahwa para wirausahawan perempuan telah memiliki ambisi untuk mencari peluang usaha karena wirausahawan perempuan lebih peka terhadap peluang usaha yang ada disekitar mereka dan para wirausahawab telah memanfaatkan peluang usaha yang ada sehingga usaha yang mereka jalankan dapat berkembang.

Kreatif dan fleksibel pada Kerajinan Perak, dalam menanggapi permintaan pasar jika ditinjau dari jenis kelamin para wirausahawan yang mayoritas perempuan, menunjukkan bahwa wirausahawan perempuan lebih kreatif dan fleksibel dalam menanggapi permintaan pasar karena wanita lebih mudah 
berhubungan dengan lingkungan sekitar sehingga informasi yang ada dilingkungan sekitar lebih mudah diperoleh dan dikembangkan dalam usahanya.

Kemampuan memimpin pada Kerajinan Perak, Kemampuan memimpin usaha jika ditinjau dari jenis kelamin para wirausahawan yang mayoritas perempuan. Jika dilihat dari kondisi lapangan, dalam mengolah usahanya para wirausahawan mayoritas menggunakan gaya kepemimpinan kekeluargaan dimana antara pemimpin dan karyawan tidak ada batasan dalam berkomunikasi secara langsung dan layaknya seperti dalam keluarga, namun sistem organisasi yang berlaku dalam usaha tetap dijalankan dengan baik. Salah satu masalah terbesar yang dihadapi orang dengan kegagalan usaha bahwa mereka terlalu cepat menilai situasisituasi tertentu dalam hidupnya dan menganggapnya sebagai kegagalan. Sebenarnya mereka perlu mengingat bahwa kegagalan itu baru sebagian kecil dari pekerjaan yang harus diselesaikan untuk sebuah pekerjaan besar.

$\begin{array}{lr} & \text { Adapun faktor-faktor penting } \\ \text { yang menunjukkan seseorang } & \text { san } \\ \text { berkomitmen tinggi terhadap }\end{array}$
pekerjaannya adalah sebagai berikut : 1) mempunyai dedikasi, 2) mencintai pekerjaannya, 3) ingin menjadi contoh bagi yang lain, 4) tidak ingin menjadi seorang pengecut, 5) profesionalisme membuat ia selalu memegang janjinya, 6) berorientasi pada mutu hasil kerjanya, 7) selalu bisa mengendalikan dirinya, 8) tekun dan ulet dalam bekerja, 9) keyakinan diri dan kedisiplinan sebagai kunci pokok. (Mendro, 2011)
Seorang wirausahawan yang berhasil selalu memiliki sifat kepemimpinan, kepeloporan, ketauladanan. Ia selalu ingin tampil berbeda, lebih dulu, lebih menonjol. Dengan menggunakan kemampuan kreatifitas dan survei, ia selalu menampilkan barng dan jasa-jasa baru dan berbeda sehingga ia menjadi pelopor baik dalam proses produksi maupun pemasaran.

Wirausahawan selalu memanfaatkan perbedaan sebagai suatu yang menambah nilai. Karena itu, perbedaan bagi seorang yang memiliki jiwa kewirausahaan merupakan sumber pembaharuan untuk menciptakan nilai. Ia selalu ingin bergaul untuk mencari peluang, terbuka untuk menerima kritik dan saran yang kemudian dijadikan peluang. Dalam karya dan karsanya wirausaha selalu ingin tampil baru dan berbeda. Karya dan karsa yang berbeda akan dipandang sebagai sesuatu yang baru dan dijadikan peluang.

Nilai inovatif, kreatif dan fleksibel merupakan unsur-unsur keberhasilan seseorang. Wirausaha yang inovatif adalah orang yang kreatif dan yakin dengan adanya caracara baru yang lebih baik (Yuyun, Wirasasmita, 1994:7). Ciri-cirinya adalah : a) tidak pernah puas dengan cara-cara yang dilakukan saat ini meskipun cara tersebut cukup baik, b) selalu menuangkan imajinasi dalam pekerjaannya, c) selalu ingin tampil berbeda atau selalu memanfaatkan perbedaan (Suryana, 2003). Usia wirausahawan yang ada di Kota lumajang mayoritas antara 41 sampai 50 tahun. Menurut Buchari Alma (2009), satu hal yang perlu diingat ialah interpreneurial experience is 
one of the best predicture of succes. Oleh sebab itu kebanyakan usaha ini tidak ada masalahn namun yang bersangkutan kurang dalam pengalaman, atau terlambat dalam melangkah.

Jika ditinjau dari jenis kelamin para wirausahawan dapat diketahui bahwa mayoritas berjenis kelamin perempuan, hal ini bisa diartikan bahwa baik laki-laki maupun perempuan sama-sama memiliki potensi yang sama untuk berhasil. Menurut Suryana (2003), dahulu, kewirausahaan dinggap hanya dapat dilakukan melalui pengalaman langsung dilapangan dan merupakan bakat yang dibawa sejak lahir (interpreneurship are born not made), sehingga kewirausahaan tidak dapat dipelajari dan diajarkan.

Sekarang wirausahawan bukan hanya urusan lapangan tetapi merupakan dijadikan ilmu yang dapat dipelajari dan diajarkan "enterpreneurship are not only born but made", artinya kewirausahaan tidak hanya bakat bawaan sejak lahir atau urusan pengalaman lapangan, tetapi juga dapat dipelajari dan diajarkan. Seseorang yang memiliki bakat kewirausahaan dapat mengembangkan bakatnya melalui pendidikan, mereka yang menjadi interpreneur adalah orang-orang yang mengenal potensi dan belajar mengembangkan potensi untuk menangkap peluang serta mengorganisir usaha dalam mewujudkan cita-citanya. Oleh karena itu, untuk menjadi wirausaha yang sukses, memiliki bakat saja tidak cukup, tetapi juga harus memiliki pengetahuan mengenai segala aspek usaha yang akan dilakukannya.
Ditinjau dari tingkat pendidikan, mayoritas wirausahawan produk unggulan Usaha Kecil Menengah Kota lumajang tingkat pendidikannya Sekolah Dasar dan Sekolah Menengah Pertama. Menurut Hendri (2011), semakin tinggi tingkat pendidikan seseorang maka semakin kecil pengaruhnya terhadap keinginan untuk memilih pengusaha sebagai jalan hidupnya. Rata-rata justru mereka yang tingkat pendidikannya tidak terlalu tinggi yang mempunyai hasrat yang kuat untuk memilih karier menjadi seorang pengusaha (karena itu jalan satusatunya untuk kaya dan sukses).

Rata-rata yang mempunyai prestasi akademi yang tidak tinggi justru mempunyai keinginan yang lebih kuat untuk menjadi seorang pengusaha. Hal ini didukung oleh sesuatu keadaan yang memaksa ia berfikir untuk menjadi pengusaha adalah salah satu pilihan terakhir untuk sukses, sedangkan untuk berkarier di dunia pekerjaan dirasakan sangat berat, mengingat persaingan yang sangat ketat dan masih banyak lulusan yang belum mendapatkan pekerjaan.

Keberhasilan dan kegagalan wirausaha sangat tergantung pada kemampuan pribadi wirausahawan. Menurut Zimmere potensi yang membuat seseorang mundur dari kewirausahaan adalah perlu kerja keras dan waktu yang lama. Wirausaha biasanya bekerja sendiri mulai dari pembelian, pengolahan, penjualan dan pembukuan. Waktu yang lama dan keharusan bekerja keras dalam berwirausaha mengakibatkan oarng yang ingin menghadapi wirausaha menjadi mundur, ia kurang terbiasa dalam 
menghadapu tantangan. Wairausaha yang berhasil pada umumnya menjadikan tantangan sebagai peluang yang harus dihadapi dan diskusi (Suryono, 2003).

Seorang wirausahawan harus memiliki mental yang kuat dalam menjalankan usaha, terlebih pada wirausahawan yang akan memulai usaha, mereka akan menghadapi tantangan yang lebih besar, kemampuan untuk membaca pasar harus dimiliki oleh seorang wirausahawan.

\section{SIMPULAN}

Berdasarkan hasil kesimpulan diatas, bahwa karakteristik sikap dan perilaku kewirausahaan yang dimilik para wirausahawan sudah baik. Jika dilihat dari hasil analisis terdapat 4 karakteristik yang masuk kategori sangat tinggi dan 8 karakteristik masuk kategori tinggi, artinya sejauh ini jiwa kewirausahaan yang melekat pada para wirausahawan sangat berperan dalam meraih kesuksesan usaha. Namun jika dilihat dari kondisi yang ada dilapangan para wirausahawan dirasa masih perlu untuk menggali dan menerapkan kriteria karakteristik sikap dan perilaku kewirausahaan diatas agar kesuksesan yang mereka capai bisa optimal.

Hasil penelitian ini diharapkan dapat bermanfaat bagi para wirausahawan sebagai tolak ukur dalam usaha memaksilamlkan pencapaian tujuan yang memiliki landasan teori serta pendapat dari berbagai ahli sehingga dapat

digunakan sebagai bahan intropeksi terhadap usaha yang telah dilakukan. Setelah itu diharapkan bagi para wirausahawan dapat termotivasi untuk menggali karakteristik sikap dan perilaku kewirausahaan mereka yang mayoritas masih belum optimal, sehingga mereka dapat mencapai keberhasilan dalam menjalankan usaha secara optimal.

\section{DAFTAR PUSTAKA}

Abu Ahmadi.1999. Bentuk

Pengukuran Sikap. Jakarta:

Grafindo

Alma, Buchari. 2009. Kewirausahaan Edisi Revisi, Bandung: AlfaBeta

Falikhin. (2010). Ananalisis Karakteristik Individu dengan Sikap dan Perilaku Kewirausahaan pada Wirausahawan Produk Unggulan Kecil dan Menengah Kota Malang. UMM Press. Malang.

Hendro, 2011. Dasar-Dasar Kewirausahaan: Panduan bagi Mahasiswa untuk mengenal, memahami, dan memasuki dunia bisnis, Jakarta: Erlangga.

Ivancevich John M., Robert Konopaske edisi 7. 2005, Karakterisktik dalam perilaku Organisasi, bandung: Prentice-hall International.

Kasmir. 2006. Kewirausahaan. Jakarta: RajaGrafindo Persada.

Martono, Nanang. 2010. Metode Penelitian Kuantitatif: Analisis Isi Dan Analisis Data Sekunder. Jakarta: PT, Rajagrafindo Persada.

Meng, Liang. 1996. Entrepreneurs, Entrepreneurship \& Entreprising Culture. Paris: Addison - Wisley Publishing 
Company.

Mohyi, Ach. 2009, Teori dan Perilaku Organisasi. Malang: Umm Press.

Robbins, Stepen P. 2001, Organization Theory:

Structure, Design, and Aplications. London: Prentice-hall International, Inc.

Robbins, Stepen. 2003. Perilaku Organisasi, Edisi Bahasa Indonesia. Jakarta: PT Indeks. Santoso, Tjiptono.2004. Perilaku kewirausahaan, Jakarta: RajaGrafindo Persada

Sigit, Soehardi, Esensi Perilaku Organisasional, Yogyakarta: BPFE UST.

Sugiyono. 2008. Metode Penelitian Bisnis. Bandung: Alfabeta.

Singarimbun, Masri, Sofian Effendi. Metode Penelitian Survei, Jakarta: PT. Pustaka LP3ES Indonesia.
Suryana, 2009, Kewirausahaan: Pedoman Praktis, Kiat dan Proses Menuju Sukses; Edisi Revisi, Jakarta: Salemba Empat.

Winardi, J. 2003, Entrepreneur \& Entrepreneurship, Jakarta: Prenada Media.

Yohanes Oktavianus dan Tjien Hin (2005). Penelitian Terdahulu. "Analisis Karakteristik Wirausaha Dalam Mendorong Kesuksesan Pengerajin Kulit di Tanggulangi. UMM Press. Malang.

Zimmere, Thomas W, Norman M. Scarborough. 2004. Pengantar Kewirausahaan dan Manajemen Bisnis Kecil, Edis Bahasa Indonesia, PT Indeks, Jakarta.

www.Lumajang.co.id. Website

Resmi Kabupaten Lumajang 10 oktober 2012 